\title{
Editorial: Infectious diseases and NCDs persist despite concerted effort
}

DOI: https://dx.doi.org/10.4314/ahs.v21i2.1

James K Tumwine

Cite as: Tumwine JK. Editorial: Infectious diseases and NCDs persist despite concerted effort. Afri Health Sci. 2021;21(2): i-v. https:// dx.doi.org/10.4314/abs.v21i2.1

Welcome to this June 2021 issue of African Health Sciences which is rich in innovative research and practice papers from all over the world. We have purposely kept away from Covid-19 this season because it was distorting our perception of ill health in Africa and beyond. Hence we have focused largely on infectious diseases. Our first paper comes from Egypt. El- Domany and colleagues ${ }^{1}$ report carbapenem resistant genes in Klebsiella pneumonia. It is followed by an interesting paper on genotypic detection of extended spectrum $\beta$-lactamases among Escherichia coli and Klebsiella pneumoniae isolates from type 2 diabetic patients with urinary tract infections keeping the Klebsiella theme alive ${ }^{2}$. Number 3 goes to: yes, Klebsiella again! It is to a paper on the prevalence and antimicrobial susceptibility of extended-spectrum beta lactamases-producing Escherichia coli and Klebsiella pneumoniae isolated in selected hospitals of Anyigba, Nigeria ${ }^{3}$. No runners up!

But our next paper is on 'bacterial profile and their antimicrobial susceptibility patterns in patients admitted at Madda Walabu University Goba Referral Hospital, Ethiopia.'4. It is followed by a paper on brucellosis and its risk factors in humans and domestic ruminants in Kagera, Tanzania. ${ }^{5}$ Still in Tanzania, we have an interesting paper on bacterial vaginosis, the leading cause of genital discharge among women presenting with vaginal infection in Dar es Salaam. ${ }^{6}$

Asefa and others ${ }^{7}$ applied the Integrated Behavioral Model (IBM) to measure intention 'to get early screening and treatment of Sexually Transmitted Infections (STIs) by HIV at- risk sub-populations' in Ethiopia. On the other hand, we have a report on unsafe sexual practices among truck drivers in India. ${ }^{8}$

This is followed by papers on urinary tract infections in Turkey ${ }^{9}$, oral health related quality of life among HIV positive patients in Nigeria ${ }^{10}$; and community pharmacists' management of self-limiting infections ${ }^{11}$. We continue with papers on sexually transmitted infections among pregnant women in The Gambia ${ }^{12}$; experiences of sex workers accessing HIV care services in Zimbabwe ${ }^{13}$ and virologic suppression and associated factors in HIV infected Ugandan female sex workers ${ }^{14}$.

Then follows the prevalence and density of malaria parasitaemia amongst HIV individuals in Nigeria $;{ }^{15}$ and evaluation of postal service for referral of specimens of drug resistant tuberculosis in Ethiopia. ${ }^{16}$

Muzanyi and colleagues ${ }^{17}$ have written for us a paper on the 'threat of persistent bacteria and fungi contamination in tuberculosis sputum cultures' and we have a paper on factors associated with self-medication with antibiotics among University students in Tanzania. ${ }^{18} \mathrm{We}$ end this treatise on infections with a paper on the role of body temperature on the respiratory rate in children with acute respiratory infections. ${ }^{19}$

Now to cancer. We have several oncology papers. First, Uganda authors ${ }^{20}$ have written on 'detecting subclinical anthracycline therapy related cardiac dysfunction'; while Ghanaian workers bring to us theirs on 'awareness and knowledge about prostate cancer among male teachers. ${ }^{21}$ Then we have several papers on potential anticancer activity of on selected herbs ${ }^{22,23}$; followed by a case report ${ }^{24}$ on 'transient bone marrow hypoplasia preceding T-Cell acute lymphoblastic leukemia.' We end this section on cancer with a molecular study on nucleophosmin 1(NPM1) gene in acute myeloid leukemia ${ }^{25}$.

We continue this NCDs work with papers on diabetes mellitus. These include risk factors for type 2 diabetes mellitus in Nigeria ${ }^{26}$; and prediction of prevalence of type 2 diabetes in Rwanda. ${ }^{27}$ Kenyan scientists ${ }^{28}$ have written for us a seminal paper on 'glycemic index values of traditional Kenyan foods.' They contend that these values might be the missing link 'in the effectiveness of dietary approach in the prevention and management of diabetes mellitus.' Nigeria workers ${ }^{29}$, on the other hand, end this section on diabetes mellitus with a piece on 'Streptozotocin-induced type 1 and 2 diabetes in rodents:' a model for studying diabetic cardiac autonomic neuropathy.'

NCDs continue. We have papers on 'circulatory microRNA expression profile for coronary artery calcification in chronic kidney disease patients; ${ }^{30}$ and one on the 'evaluation of three different laboratory methods to detect 'human leukocyte antigen antibodies in a South African kidney transplant population. ${ }^{31}$

(C) 2021 Tumwine JK. Licensee African Health Sciences. This is an Open Access article distributed under the terms of the Creative commons Attribution License (https://creativecommons.org/licenses/BY/4.0), which permits unrestricted use, distribution, and reproduction in any medium, provided the original work is properly cited. 
Now to the clinical. Nigerian clinicians have a paper on the relationships between 'cardiovascular signs and neurological signs in asphyxiated neonates. ${ }^{32}$ This paper is followed by several on sickle cell anemia: 'the burden of iron overload among non-chronically blood transfused preschool children ${ }^{33}$; disease severity and folate status $^{34}$; utilization and provider-related barriers to the use of hydroxyurea in the treatment of sickle cell disease patients, ${ }^{35}$ and psycho-social problems of adolescents with sickle-cell anaemia. ${ }^{36}$ The section ends with an interesting blood transfusion paper on the utility of 'home-made' reagent red blood cells for antibody screening during pre-transfusion compatibility testing in Uganda. ${ }^{37}$

We have several papers on injury: traumatic spinal cord injury and clinical complications; ${ }^{38}$ acute kidney injury among medical and surgical in-patients in Ghana; ${ }^{39}$ mortality and its determinants after fragility hip fractures from Egypt ${ }^{40}$; and risk factors for childhood injuries in Tanzania. ${ }^{41}$ ending with a study of sports medicine practices for athletes in Uganda. ${ }^{42}$

We bring you several papers on sexuality: a new grading system for female sexual dysfunction in Egyptian women $^{43}$; and one on menstrual hygiene management among adolescent school girls in Nigeria. ${ }^{44} \mathrm{~A}$ case report on refractory convulsive syncope in pregnancy and Takayasu's arteritis ${ }^{45}$ ends that brief section on sexuality. Some reflections on mental health include: effects of black tea consumption on depression ${ }^{46}$; genetic influence of Apolipoprotein E gene $\varepsilon 2 / \varepsilon 3 / \varepsilon 4$ isoforms on odds of mesial temporal lobe epileps $\mathrm{y}^{47}$; and correlates of substance use among undergraduates in a low income country. ${ }^{48} \mathrm{~A}$ rare paper on 'psychological ailments and their treatment protocols based on a study of Swati traditional healers in Mpumalanga Province, in South Africa concludes the mental health section. ${ }^{49}$

The remaining papers are on diverse issues such as availability of low vision services in Ghana, ${ }^{50}$ utilization and uptake of the UpToDate clinical decision support tool51 at Makerere University in Uganda ${ }^{51}$; hearing healthcare gaps in a semi-urban community in Nigeria ${ }^{52}$. A paper on 'upper gastrointestinal endoscopy findings in Uganda ${ }^{53}$; together with one on nutrition education on BMI-for-age in Ghanaian school-aged children ${ }^{54}$; and factors contributing to obesity and overweigh in Morocco $^{55}$ give a glimpse on some aspects of nutrition in the continent. The effect of call reminders, short message services (SMS) reminders, and SMS immunization facts on childhood routine vaccination timing and completion in Nigeria ${ }^{56}$ reminds us of the potential for innovative technology in the health sector in Africa. We end this reflection on the June 2021 issue of African Health Sciences on a high note: the 'clinical description and mutational profile of a Moroccan series of patients with Rubinstein Taybi syndrome. ${ }^{57}$.

We thank all our readers, authors, reviewers, our team of highly dedicated volunteers, collaborators, partners and colleagues for their immeasurable contribution to African Health Sciences: the home of truly free online publishing in Africa!

\section{References}

1. El-Domany RA, El-Banna T, Sonbol F, AbuSayedahmed SH. Co-existence of NDM-1 and OXA48 genes in Carbapenem Resistant Klebsiella pneumoniae clinical isolates in Kafrelsheikh, Egypt. Afri Health Sci. 2021;21(2). 489-496. https://dx.doi.org/10.4314/ ahs.v21i2.2

2. Elmi SYK, Ashour MS, Alsewy FZ, Azzam NFA-M. Phenotypic and genotypic detection of extended spectrum $\beta$-lactamases among Escherichia coli and Klebsiella pneumoniae isolates from type 2 diabetic patients with urinary tract infections. Afri Health Sci. 2021;21(2). 497-504. https://dx.doi.org/10.4314/ahs.v21i2.3

3. Mofolorunsho KC, Ocheni HO, Aminu RF, Omatola CA, Olowonibi OO. Prevalence and antimicrobial susceptibility of extended-spectrum beta lactamases-producing Escherichia coli and Klebsiella pneumoniae isolated in selected hospitals of Anyigba, Nigeria. Afri Health Sci. 2021;21(2). 505-512. https://dx.doi. org/10.4314/ahs.v21i2.4

4. Gemechu MM, Tadesse TA, Takele GN, Bisetegn FS, Gesese YA, Zelelie TZ. Bacterial profile and their antimicrobial susceptibility patterns in patients admitted at MaddaWalabu University Goba Referral Hospital, Ethiopia: a cross sectional study. Afri Health Sci. 2021;21(2). 513-522. https://dx.doi.org/10.4314/ahs.v21i2.5

5. Ntirandekura JB, Matemba LE, Kimera SI, Muma JB, Karimuribo ED. Brucellosis and its associated risk factors to humans and domestic ruminants in Kagera Ecosystem, Tanzania. Afri Health Sci. 2021;21(2). 523530. https://dx.doi.org/10.4314/ahs.v21i2.6

6. Majigo MV, Kashindye P, Mtulo Z, Joachim A. Bacterial vaginosis, the leading cause of genital discharge among women presenting with vaginal infection in Dar es Salaam, Tanzania. Afri Health Sci. 2021;21(2). 531537. https://dx.doi.org/10.4314/ahs.v21i2.7

7. Alemayehu WA, Maritz J, Roets L. Application of Integrated Behavioral Model (IBM) to measure intention to get early screening and treatment of Sexually Trans- 
mitted Infections (STIs) among HIV at- risk sub-populations in Ethiopia. Afri Health Sci. 2021;21(2). 538-546. https://dx.doi.org/10.4314/ahs.v21i2.8

8. Pundhir A, Shukla A, Goel AD, Pundhir P, Gupta MK, Parashar P, et al. Exploring unsafe sexual practices among truck drivers at Meerut District, India: a cross-sectional study. Afri Health Sci. 2021;21(2). 547556. https://dx.doi.org/10.4314/ahs.v21i2.9

9. Celep G, Özçelik HB. Evaluation of clinical, etiological and antimicrobial resistance profile of pediatric urinary tract infections in a secondary health care centre. Afri Health Sci. 2021;21(2). 557-565. https://dx.doi. org/10.4314/ahs.v21i2.10

10. Umeizudike KA, Osagbemiro BB, Daramola OO, Adeyemo TA. Oral health related quality of life among HIV positive patients attending two HIV outpatient clinics in Nigeria - a cross sectional study. Afri Health Sci. 2021;21(2). 566-575. https://dx.doi.org/10.4314/ ahs.v21i2.11

11. Akpan RM, Udoh EI, Akpan SE, Ozuluoha CC. Community pharmacists' management of self-limiting infections: a simulation study in Akwa Ibom State, South-South Nigeria. Afri Health Sci. 2021;21(2). 576584. https://dx.doi.org/10.4314/ahs.v21i2.12

12. Isara A, Baldeh A-K. Prevalence of sexually transmitted infections among pregnant women attending antenatal clinics in West Coast Region of The Gambia. Afri Health Sci. 2021;21(2). 585-592. https://dx.doi. org/10.4314/ahs.v21i2.13

13. Moyo I, Macherera M. The experiences of sex workers accessing HIV care services in Bulawayo, Zimbabwe. Afri Health Sci. 2021;21(2). 593-602. https://dx. doi.org/10.4314/ahs.v21i2.14

14. Owachi D, Anguzu G, Kigozi J, Cox J, Castelnuovo B, Semitala F, et al. Virologic suppression and associated factors in HIV infected Ugandan female sex workers: a cross-sectional study. Afri Health Sci. 2021;21(2). 603-613. https://dx.doi.org/10.4314/ahs.v21i2.15

15. Jemikalajah JD, Anie CO, Enwa FO. Prevalence and density of malaria parasitaemia amongst HIV Individuals in Warri, Nigeria. Afri Health Sci. 2021;21(2). 614 618. https://dx.doi.org/10.4314/ahs.v21i2.16

16. Gebregergs GB, Sinishaw MA, Shiferaw MB, Antife T, Assefa M, Fiseha D, et al. Evaluation of the postal service for referral of specimen of drug resistance tuberculosis in Amhara region, Ethiopia; mixed method. Afri Health Sci. 2021;21(2). 619-627. https://dx.doi. org/10.4314/ahs.v21i2.17

17. Muzanyi G, Peace A, Wamuntu B, Joseph A, Nassali $\mathrm{J}$. The threat of persistent bacteria and fungi contamination in tuberculosis sputum cultures. Afri Health Sci.
2021;21(2). 628-632. https://dx.doi.org/10.4314/ahs. v21i2.18

18. Chuwa BB, Njau LA, Msigwa KI, Shao E. Prevalence and factors associated with self medication with antibiotics among University students in Moshi Kilimanjaro Tanzania. Afri Health Sci. 2021;21(2). 633-639. https://dx.doi.org/10.4314/ahs.v21i2.19

19. Ozdemır B, Yalçın SS. The role of body temperature on respiratory rate in children with acute respiratory infections. Afri Health Scii. 2021;21(2). 640-646. https:// dx.doi.org/10.4314/ahs.v21i2.20

20. Zhang W, Azibani F, Okello E, Kayima J, Walusansa V, Orem J, et al. Rational and design of SATRACD study: detecting subclinical anthracycline therapy related cardiac dysfunction in low income country. Afri Health Sci. 2021;21(2). 647-654. https://dx.doi.org/10.4314/ ahs.v21i2.21

21. Asare B Y-A, Ackumey MM. Awareness and knowledge about prostate cancer among male teachers in the Sunyani Municipality, Ghana. Afri Health Sci. 2021;21(2). 655-662. https://dx.doi.org/10.4314/ahs.v21i2.22

22. Ndlovu MJ, Bagla VP, Mokgotho MP, Makgatho ME, Matsebatlela TM. Potential anticancer activity of Acetone extracts of Toona cilliata, Seriphium plumosum and Schkuhria pinnata on HeLa cervical cancer cells. Afri Health Sci. 2021;21(2). 663-672. https://dx. doi.org/10.4314/ahs.v21i2.23

23. Ndiokwelu UF, Ogunkanmi LA, Minari JB, Uzoma IC. Allium sativum aqueous extract does not have chemo-protective effect on etoposide induced therapy-related DNA damage leading to Acute Myeloid Leukemia in albino-wistar rats. Afri Health Sci. 2021;21(2). 673-682. https://dx.doi.org/10.4314/ahs.v21i2.24

24. Naturinda E, George P, Ssenyondwa J, Bakulumpagi D, Lubega J, Wasswa P. Transient bone marrow hypoplasia preceding T-Cell acute lymphoblastic leukemia: a case report. Afri Health Sci. 2021;21(2). 683-686. https://dx.doi.org/10.4314/ahs.v21i2.25

25. Othman GO, Mohammad NS, Saeed CH. Molecular study of Nucleophosmin 1(NPM1) gene in acute myeloid leukemia in Kurdish population. Afri Health Sci. 2021;21(2). 687-692. https://dx.doi.org/10.4314/ahs. v21i2.26

26. Iheanacho CO, Osoba DO, Eze UIH. Evaluation of predominant risk factors for type 2 diabetes mellitus among out-patients in two Nigerian secondary health facilities. Afri Health Sci. 2021;21(2). 693-701. https:// dx.doi.org/10.4314/ahs.v21i2.27

27. Dukunde A, Ntaganda JM, Kasozi J, Nzabanita J. Prediction of prevalence of type 2 diabetes in Rwanda using the metropolis-hasting sampling. Afri Health Sci. 
2021;21(2). 702-709. https://dx.doi.org/10.4314/ahs. v21i2.28

28. Ebere R, Imungi J, Kimani V. Glycemic index values of traditional Kenyan foods: the missing link in the effectiveness of dietary approach in the prevention and management of diabetes mellitus in Kenya. Afri Health Sci. 2021;21(2). 710-718. https://dx.doi.org/10.4314/ ahs.v21i2.29

29. Akinlade OM, Owoyele BV, Soladoye AO. Streptozotocin-induced type 1 and 2 diabetes in rodents: a model for studying diabetic cardiac autonomic neuropathy. Afri Health Sci. 2021;21(2). 719-727. https:// dx.doi.org/10.4314/ahs.v21i2.30

30. Vijayaraghavan B, Jeyamohan S, Padmanabhan G, Velangann AJ, Ramanathan K. Circulatory microRNA expression profile for coronary artery calcification in chronic kidney disease patients. Afri Health Sci. 2021;21(2). 728-734. https://dx.doi.org/10.4314/ahs. v21i2.31

31. Kwofie L, Anderson R, Steel H, Meyer PWA. Evaluation of three different laboratory methods to detect preformed human leukocyte antigen antibodies in a South African kidney transplant population. Afri Health Sci. 2021;21(2). 735-742. https://dx.doi.org/10.4314/ ahs.v21i2.32

32. Issa A, Abdulkadir MB, Adesiyun OO, Owolabi B, Suberu H, Alabi KO, et al. Relationships between cardiovascular signs and neurological signs in asphyxiated neonates in Ilorin, North Central Nigeria. Afri Health Sci. 2021;21(2). 743-752. https://dx.doi.org/10.4314/ ahs.v21i2.33

33. Olufemi AS, Folashade AA, Adetutu OT. Burden of iron overload among non-chronically blood transfused preschool children with sickle cell anaemia. Afri Health Sci. 2021;21(2). 753-758. https://dx.doi.org/10.4314/ ahs.v21i2.34

34. Nnajekwu UC, Nnajekwu CO, Onukwuli VO, Uwaezuoke NA, Ezenwosu OU, Ikefuna AN, et al. Relationship between disease severity and folate status of children with sickle cell anaemia in Enugu, South East Nigeria. Afri Health Sci. 2021;21(2). 759-764. https:// dx.doi.org/10.4314/ahs.v21i2.35

35. Ofakunrin AOD, Okpe ES, Afolaranmi TO, Olaosebikan RR, Kanhu PU, Adekola K, et al. Level of utilization and provider-related barriers to the use of hydroxyurea in the treatment of sickle cell disease patients in Jos, North-Central Nigeria. Afri Health Sci. 2021;21(2). 765-774. https://dx.doi.org/10.4314/ahs. v21i2.36

36. Adegboyega LO. Psycho-social problems of adolescents with sickle-cell anaemia in Ekiti State, Nigeria.
Afri Health Sci. 2021;21(2). 775-781. https://dx.doi. org $/ 10.4314 /$ ahs.v21i2.37

37. Natukunda B, Wagubi R, Taremwa I, Okongo B, Mbalibulha Y, Teramura G, et al. The utility of 'homemade' reagent red blood cells for antibody screening during pre-transfusion compatibility testing in Uganda. Afri Health Sci. 2021;21(2). 782-787. https://dx.doi. org/10.4314/ahs.v21i2.38

38. Moshi HI, Sundelin GG, Sahlen KG, Sörlin AVM. A one-year prospective study on the occurrence of traumatic spinal cord injury and clinical complications during hospitalisation in North-East Tanzania. Afri Health Sci. 2021;21(2). 788-794. https://dx.doi.org/10.4314/ ahs.v21i2.39

39. Ephraim RKD, Awuku YA, Tetteh-Ameh I, Baffe C, Aglagoh G, Ogunajo VA, et al. Acute kidney injury among medical and surgical in-patients in the Cape Coast Teaching Hospital, Cape Coast, Ghana: a prospective cross-sectional study. Afri Health Sci. 2021;21(2). 795805. https://dx.doi.org/10.4314/ahs.v21i2.40

40. Abdelnasser MK, Khalifa AA, Amir KG, Hassan MA, Eisa AA, El-Adly WY, et al. Mortality incidence and its determinants after fragility hip fractures: a prospective cohort study from an Egyptian level one trauma center. Afri Health Sci. 2021;21(2). 806-816. https:/ / dx.doi.org/10.4314/ahs.v21i2.41

41. Moshiro R, Furia FF, Massawe A, Mmbaga EJ. Pattern and risk factors for childhood injuries in Dar es Salaam, Tanzania. Afri Health Sci. 2021;21(2). 817-825. https://dx.doi.org/10.4314/ahs.v21i2.42

42. Lubega SK, Makubuya T, Muwonge H, Lambert M. A descriptive prospective study of sports medicine practices for athletes in Uganda. Afri Health Sci. 2021;21(2). 826-834. https://dx.doi.org/10.4314/ahs. v21i2.43

43. Ismail SA, Abdel-Azim NE, Saleh MA, Mohamed AA, Yosef AH, Abbas AM. A new grading system for female sexual dysfunction based on the female sexual function index in Egyptian women: a cross-sectional study. Afri Health Sci. 2021;21(2). 835-841. https://dx. doi.org/10.4314/ahs.v21i2.44

44. Nnennaya EU, Atinge S, Dogara SP, Ubandoma RJ. Menstrual hygiene management among adolescent school girls in Taraba State, Nigeria. Afri Health Sci. 2021;21(2). 842-851. https://dx.doi.org/10.4314/ahs. v21i 2.45

45. Alobo G, Nahurira V, Omona V, Bayo P, Olum S. Refractory convulsive syncope in pregnancy: a rare presentation of Takayasu's arteritis - a case report and literature review. Afri Health Sci. 2021;21(2). 852-857. https://dx.doi.org/10.4314/ahs.v21i2.46 
46. Asil E, Yllmaz MV, Yardimci H. Effects of black tea consumption and caffeine intake on depression risk in black tea consumers. Afri Health Sci. 2021;21(2). 858865. https://dx.doi.org/10.4314/ahs.v21i2.47

47. Xu T, Zhang H, Qiu X, Meng Y. Genetic influence of Apolipoprotein $\mathrm{E}$ gene $\varepsilon 2 / \varepsilon 3 / \varepsilon 4$ isoforms on odds of mesial temporal lobe epilepsy. Afri Health Sci. 2021;21(2). 866-874. https://dx.doi.org/10.4314/ahs. v21i 2.48

48. Aguocha CM, Nwefoh E. Prevalence and correlates of substance use among undergraduates in a developing country. Afri Health Sci.2021;21(2). 875-883. https://dx.doi.org/10.4314/ahs.v21i2.49

49. Ngobe A, Semenya S, Sodi T. Psychological ailments and their treatment protocols: a case study of Swati traditional healers in Mpumalanga Province, South Africa. Afri Health Sci. 2021;21(2). 884-895. https://dx.doi. org/10.4314/ahs.v21i2.50

50. Kyeremeh S, Mashige KP. Availability of low vision services and barriers to their provision and uptake in Ghana: practitioners' perspectives. Afri Health Sic. 2021;21(2). 896-903. https://dx.doi.org/10.4314/ahs. v21i2.51

51. Kinengyere AA, Rosenberg J, Pickard O, Kamya M. Utilization and uptake of the UpToDate clinical decision support tool at the Makerere University College of Health Sciences (MakCHS), Uganda. Afri Health Sci. 2021;21(2). 904-911. https://dx.doi.org/10.4314/ahs. v21i 2.52

52. Adeyemo A, Ogunkeyede S, Dania O. Hearing healthcare gaps in LMICS: snapshot from a semi-urban community in Nigeria. Afri Health Sci. 2021;21(2). 912918. https://dx.doi.org/10.4314/ahs.v21i2.53

53. Doe MJ, Bua E, Obbo JSO, Bisso F, Olupot-Olupot P. Upper gastrointestinal endoscopy findings in Mbale Regional Referral Hospital, Eastern Uganda: a 10-year retrospective analysis. Afri Health Sci. 2021;21(2). 919926. https://dx.doi.org/10.4314/ahs.v21i2.54

54. Annan RA, Apprey C, Agyemang GO, Tuekpe DM, Asamoah-Boakye O, Okonogi S, et al. Nutrition education improves knowledge and BMI-for-age in Ghanaian school-aged children. Afri Health Sci. 2021;21(2). 927941. https://dx.doi.org/10.4314/ahs.v21i2.55

55. Boukrim M, Obtel M, Lahlou L, Razine R. University students' perceptions and factors contributing to obesity and overweigh in Southern of Morocco. Afri Health Sci. 2021;21(2). 942-950. https://dx.doi.org/10.4314/ ahs.v21i 2.56

56. Ibraheem R, Akintola M, Abdulkadir M, Ameen $\mathrm{H}$, Bolarinwa O, Adeboye M. Effects of call reminders, short message services (SMS) reminders, and SMS immunization facts on childhood routine vaccination timing and completion in Ilorin, Nigeria. Afri Health Sci. 2021;21(2). 951-959. https://dx.doi.org/10.4314/ahs. v21i2.57

57. Elalaoui SC, Smaili W, Van-Gils J, Fergelot P, Ratbi I, Tajir M, et al. Clinical description and mutational profile of a Moroccan series of patients with Rubinstein Taybi syndrome. Afri Health Sci. 2021;21(2). 960-967. https://dx.doi.org/10.4314/ahs.v21i2.58 